\title{
Danilo Kiš and the Hungarian Holocaust: The Early Novel Psalm 44
}

\section{John K. Cox North Dakota State University}

Abstract: Danilo Kiš's little known second novel, Psalm 44 (1962) is his first major prose work about the Holocaust. This novel was published for the first time in Hungarian translation in 1966 and English translation in 2012. The novel is quite different from Kiš's later works on the Holocaust, the autobiographical trilogy comprising Early Sorrows, Garden, Ashes, and Hourglass. The first difference is in setting. In Psalm 44, a number of important flashbacks take place in Ujvidék/Novi Sad, the region of northern Serbia (then Yugoslavia) under Hungarian occupation after 1941; much of the rest of the book takes place in Auschwitz and associated camps in Poland. The amount of Hungarian material is significant, but the inclusion of so much material from Auschwitz is not found elsewhere in Kiš's oeuvre. The second difference is in the author's graphic portrayal of gruesome atrocities. For the literary historian, Psalm 44 is an important milestone in the development of Kiš 's thematic and stylistic inventory. For other historians, the novel functions in part as a microhistory of the Újvidék massacres (the "Cold Days") of early 1942. Kiš 's quest to find his own voice to attempt to convey the tragedy of the Holocaust - as important for the entire human family and the very region of Central Europe as it was for his own family - finds a parallel expression in the confusion, exhaustion, and skepticism of the characters in this novel.

Keywords: Hungary, Holocaust, Hungarian-Serbian relations, Danilo Kiš, Psalm 44, Vajdaság, Vojvodina, Újvidék, Novi Sad, Cold Days

\section{Recommended Citation}

Cox, John K. "Danilo Kiš and the Hungarian Holocaust: The Early Novel Psalm 44." AHEA: Ejournal of the American Hungarian Educators Association, Volume 5 (2012): http://ahea.net/ejournal/volume-4-2012/?

Biography: John K. Cox is professor and department head in History at North Dakota State University in Fargo. A native of North Carolina and proud graduate of Guilford College in 1986, he earned his doctorate from Indiana University in 1995. After teaching at Wheeling Jesuit University near Pittsburgh for thirteen years, he made the move to North Dakota State in 2007. The History of Serbia (2002), Slovenia: Evolving Loyalties (2005), articles on the historicity of the fiction of Ismail Kadare, and translations of novels by Danilo Kiš and Ivan Cankar are among his chief publications. He is currently translating László Végel's Egy makró emlékiratai (1969) and Vjenceslav Novak's Dva svijeta (1901), and he is also looking for a way to write a history of paprika production and consumption in Central and Southeastern Europe. 
Cox, John K. "Danilo Kiš and the Hungarian Holocaust: The Early Novel Psalm 44." AHEA: E-journal of the American Hungarian Educators Association, Volume 5 (2012): http://ahea.net/e-journal/volume-5-2012

\section{Introduction}

Danilo Kiš, born in Szabadka (Serbian: Subotica) in 1935, is an important figure in literary and intellectual history in many respects. Along with Ivo Andrić, who won the Nobel Prize for Literature in 1961, and Borislav Pekić, he is often considered one of the greatest Serbian prose writers of the twentieth century. He learned Hungarian as a child from his father, Eduard Kiš (formerly Kohn), and from the surroundings in which he grew up, both in the Vajdaság and in Zala megye, where he and his family spent several years during World War II. Indeed Danilo Kiš spoke Hungarian with friends until the end of his life in 1989, and he translated an enormous amount of Hungarian poetry into Serbo-Croatian, the language he learned from his Montenegrin mother, Milica Dragićević, and in which he crafted his own literary works. His path-breaking fiction about the Holocaust in southern Hungary, in northern Serbia, and, to a lesser extent, in the death camps in Poland contained both autobiographical and postmodern elements. Kiš also wrote several volumes of essays and Čas anatomije (Eng: The Anatomy Lesson) ${ }^{1}$, a sustained polemical exposition of literary theory, focusing in essence on intertextuality and pastiche.

Violence and political exclusion are two of the subjects on which Kiš concentrates in his fiction. Underlying his strongly held personal conviction that totalitarianism from left and right are equally lethal and reprehensible, one can discern his identification of and with the figure of the "outsider." This Other in Kiš takes many forms in various of his works, from children, women and political misfits to alcoholics, the mentally unstable, and even robots. Because of his own family's suffering during the Third Reich and the time of radical right or fascist ascendancies inYugoslavia and Hungary, and because of his own sense of being especially singled out due to his unusual, mixed background (Hungarian-Jewish-Montenegrin-Serbian) and his assumed lack of ideological or emotional "fit" with the dominant elites in both Serbia and Yugoslavia, the racial, ethnic, and religious persecutions of the 1940s form the starting point of Kiš's artistic mission. In this article, the focus will be on Kiš's representation of the Shoah in the light of his novel Psalm 44. This work, his second novel, was first published in 1962 in tandem with his first novel, The Attic. The first English rendering of Psalm 44, translated by the author of this article, has just been published by Dalkey Archive Press, which has kept a number of older translations of Kiš's works in print while bringing out new volumes as well. With Dalkey's latest releases, nine volumes of Kiš's works are available in English from a variety of translators; there exist also translations of individual Kiš poems, short stories, and a play. The first of his major works to be published in English was Garden, Ashes, part of Kiš's autobiographical trilogy, in 1975. It is the purpose of this essay to introduce anglophone readers to the little-known Psalm 44 through an analysis of its place in Kiš's evolution as a writer, in both stylistic and thematic terms, and through an examination of its high quotient of Hungarian content.

\footnotetext{
${ }^{1}$ In this study, first references to book titles in English will indicate that the work has been translated. If the first reference is in Serbo-Croatian or another language besides English, followed by an English version of the title in parentheses, this will indicate (as in the case of Čas anatomije) that no English translation of the work has been published.
} 
Cox, John K. "Danilo Kiš and the Hungarian Holocaust: The Early Novel Psalm 44." AHEA: E-journal of the American Hungarian Educators Association, Volume 5 (2012): http://ahea.net/e-journal/volume-5-2012

\section{Kiš, Hungary, and the Holocaust}

Hungary comes up in most of Kiš's fiction. Indeed he writes more often about Hungary than about his native Yugoslavia, although in interviews and essays the proportions are reversed. Since for the first twelve years of his life he lived in a bilingual Hungarian-Serbian family and region, with the last five of those years being in the fully Hungarian-speaking environment of Zala county southwest of Lake Balaton, it is natural that Kiš's autobiographical works would have a lot to do with Hungary. This connection is further strengthened, in my opinion, by the fact that the paradoxical nature and tragic fate of his bilingual father was the main inspiration for Kiš's literary activity; the years of World War II and the Holocaust shaped Kiš emotionally, esthetically, epistemologically, and politically.

A large number of Kiš's essays and interviews have been translated into English, and in many of them he discusses, albeit briefly, his childhood in Hungary and the Vajdaság. ${ }^{2}$ In others he comments on Hungarian poetry, especially in connection with writers whose work he has translated (see below). A small number of Kiš's own poems, almost all of which were written when he was relatively young, touch upon Judaism and the Holocaust, but few have specific Hungarian content. Almost all of Kiš's lyric poems are short, with his one piece of political satire about Titoism and his rapturous prose poems being the main exceptions to this characterization. Of these short poems on our subject, then, perhaps the most notable, in large part because of the beauty deriving from its vivid, tense images, is "Biografija" ("Biography"), a summary of the strange and dangerous life of Kiš's father. The other noteworthy poem on Shoah-related themes is "A Poem about a Jewish Girl," in which a young woman is executed in a landscape of powerful symbolism. "Piano, Out of Tune" contains a series of vignettes from all across Europe about loneliness and desire, and in one of them a German soldier appears to be raping a young Polish (Jewish?) woman in 1943.

There is more of the Holocaust in Kiš's plays and TV dramas. In Night and Fog (Kiš 2009) from 1967, we traverse much of the same fictionalized autobiographical terrain as in the stories of Early Sorrows, the first volume of the autobiographical "family circus"; because of its Cold War setting, though, the play is also a prime showcase for Kiš's ideas on the equivalence among totalitarian systems. On another level, this drama is also a study of the insidious unreliability of memory, both intended and unintended. The play is set in southern Hungary in the 1950s and involves an unpleasant, revelatory visit by young man who had experienced various kinds of mistreatment at the hand of two conformist village teachers during the war. They were inclined towards fascism then, and they are very much Communists at the time of his visit, and from out of the memories of the multi-ethnic character of their former common home, a village in the Vojvodina, bitter deceptions and conflicts emerge. A second play, from around 1970, is also of interest. This drama, Drveni sanduk Tomasa Vulfa (not yet translated; A Wooden Chest for Thomas Wolfe) compares the fates of two Jewish men damaged in different ways by World War II and by competing totalitarianisms; ultimately it resolves into a depiction of the painful process of writing from memory and of discerning what values are worth immortalizing through our work.

\footnotetext{
${ }^{2}$ In this essay, the terms Vajdaság (Hungarian) and Vojvodina (Serbian and English) will be used as equivalents. A related Hungarian term, Délvidék, was also in common use in Kiš's day, as now, but it can denote a somewhat larger "southern region" than the administrative unit known in the 20th century as the Vojvodina.
} 
Cox, John K. "Danilo Kiš and the Hungarian Holocaust: The Early Novel Psalm 44." AHEA: E-journal of the American Hungarian Educators Association, Volume 5 (2012): http://ahea.net/e-journal/volume-5-2012

The collection of early stories by Kiš entitled The Lute and the Scars (Kiš Lute 2012), contains a very lyrical and intimate story, "Jurij Golec," written in hommage to the highly regarded novelist Piotr Rawicz. In the later story collections, A Tomb for Boris Davidovich and The Encyclopedia of the Dead, there are many stories with Jewish characters; together, a majority of these stories are about Hungary and Russia, but all in all the stories span many time periods and regions. Kiš also wrote two other stories in Serbo-Croatian that treat the Holocaust and that have not yet been translated into English. "Juda" ("A Jew") contains references to the Szálasi movement and centers on the persecution of minorities during the war, while "Kosa" ("The Hair") treats life and death in a Jewish women's section of a concentration camp.

The most concentrated and extensive immersion in the Shoah provided by any of Kiš's works is doubtless in the three disparate volumes of what he called ironically his "family circus" (as opposed to the commonplace and pathos-soaked "family cycle"). Early Sorrows (For Children and Sensitive Readers), published in Yugoslavia in 1972 and translated into English in 1998, contains brief sketches of life in southwestern Hungary during World War II. The second book in terms of content was the first of the three to be written: Garden, Ashes, published in Serbo-Croatian in 1965 (English translation, 1975). This magnificent novel explores, in the words of its youthful narrator, the "muddy tale of [Kiš's] father" (Kiš 1994, 99) from the point of view of the author as confused youthful son and grieving adult author. A particular lapidary approach to the realia of a disappeared style of life, especially in terms of household items and nature (a coffee tray, an all-important Singer sewing machine, rows of wild chestnut trees) is now found in Kiš's prose. Things beautiful, or just well-thumbed, but in all cases well-loved and precisely, but not pedantically described, are gone. The novel runs up to the point of the "disappearance" of his father, who is a kind of messianic anti-prophet whose disappearance becomes part and parcel of the disappearance of the physical world of Central European Jewry. In Kiš's fiction, as in real life, the documentary traces of his father are scarce and often vague, and so Kiš attempts to explore people's connections to his father and also make inferences about his father whenever he can. Then, at last, we arrive at Hourglass (1972; English translation 1990). In the eyes of this observer, this is Kiš's magnum opus. We witness the father's death--actually multiple deaths, arguable as many as six of them, since Kiš is writing in his most postmodern mode here---and the ongoing tortured relationship of Danilo's family with their more assimilated relatives in southern Hungary and northern Serbia who are mostly passing as nonJewish. This is Kiš's most post-modern work in style and structure, with elements of intertextuality and a narrative structure cleverly assembled from points in a document, a letter from his father as he was about to be drafted for forced labor and eventually deported to Auschwitz, where he disappeared. Great brutality at the hands of anti-Semitic bullies and quiet but enduring longing for a way of life in the process of disappearing reside among the asides, monologues and catalogic enumerations about everything from philosophy to train schedules to the uses of the potato.

A large bibliography of articles and books by and about Kiš can be found online at www.Kiš.org.rs/web/Bzivot/A/B/E/index.htm. In 1966, Kiš's first two novels were published in Hungarian as Manzárd: két Kišregény, and between 1967 and 1994 seven more volumes of his fiction and essays appeared in Budapest, Ujvidek, or Pozsony. These included Kert, hamu; Korai bánat: gyermekek és érzékenyek számára; Fövenyóra; Borisz Davidovics síremléke: hét fejezet egy közös történetböl; A holtak enciklopédiája; Kételyek kora: Esszék, tanulmányok; and Lant és sebhelyek: novellák a hagyatékból, 1980-1986. 
Cox, John K. "Danilo Kiš and the Hungarian Holocaust: The Early Novel Psalm 44." AHEA: E-journal of the American Hungarian Educators Association, Volume 5 (2012): http://ahea.net/e-journal/volume-5-2012

Many more translations of essays and excerpts from fictional works have also appeared in periodicals.

In addition to listing all extant translations of Kiš's works into Hungarian (and many other languages), the site above also provides details works of criticism on Kiš by Hungarianlanguage scholars, as well as documentation of Kiš's translations of Hungarian poetry into SerboCroatian. Most prominent among the works of this latter category are his renderings of the poetry of Endre Ady, whose poetry had a marked influence on Kiš from a very young age; Kiš also thought very highly of Attila József, Miklós Radnóti, Ottó Tolnai, Sándor Petőfi, and György Petri, by each of whom he published at least one entire volume of verse in translations. He published translations by other Hungarian writers, as well. His first volume of translations, appearing in 1961, was Ady's Vér és arany (Serbo-Croatian: Krv i zlato), and his very first published translations, which appeared in the journal Susreti (Encounters) in 1955, were also works by Ady.

\section{The Historical Background to the Events in Psalm 44}

The Holocaust occurred as the result of the confluence of two sets of developments in the 1930s and 1940s. The first is the territorial growth of the Hungarian state, beginning in 1938, as the Trianon system began to be altered by Nazi Germany in Hungary's favor. The second line of developments involved the rapid increase of official hostility and government persecution of Jews in Hungary, as right-wing governments (including those of the ill-fated Pál Teleky, who committed suicide on the eve of the consummation of Hungary's active military alliance with Nazi Germany in the spring of 1941) gradually gave in to the chaos of war, intense pressure from and massive intervention by their German allies, and the fanaticism of the domestic Arrow Cross regime of Ferenc Szálasi after October 1944.

In 1938 and again in 1940, Budapest was the beneficiary of the two Vienna "awards," diplomatic gifts to Hungary by the Nazi regime. These arbitrations redrew the borders of Czechoslovakia and Romania, respectively, to give back to Hungary, still smarting over the losses from the Treaty of Trianon following the Great War, considerable chunks of the territory and population lost in 1920. In 1939 a smaller amount of territory in sub-Carpathian Ruthenia had also changed hands in favor of Hungary, but for our purposes the most important instance of territorial growth occurred after the Axis invasion of Yugoslavia in April 1941. Hitler allowed the Hungarian government of Regent Miklós Horthy, Prime Minister László Bárdossy, and Foreign Minister István Csáky to annex a number of regions in the northern part of Yugoslavia. The Germans' chief concerns at the time lay in punishing a recalcitrant and unpredictable (sometimes pro-British, sometimes pro-Soviet) Serbian-dominated government in Royal Yugoslavia and in opening up invasion routes to Greece; later, mineral extraction, requisitioned labor and cannon fodder for the Eastern Front, and rewarding cooperative puppet regimes will dominate the German agenda. But nothing spoke against transferring many of the northern expanses of the country, overwhelmingly agricultural and in many places containing large Hungarian populations, to Berlin's new Danubian ally. Chief among these transferred territories were the Yugoslav portions of Baranja, Bačka, Srem, and Banat, all of which had at various times, in whole or in part, been included in the historical region known as the Vajdaság or Vojvodina. Hungary thus recouped some, though not all, of its post-World War I losses. Over two million Hungarians, and many others, now lived again under Budapest's rule. The family of Danilo Kiš was among them. His father had lived as a young man in Szombathely, but seems to have chosen to live in the Vojvodina when sovereignty was transferred after 1918, where he worked as an 
Cox, John K. "Danilo Kiš and the Hungarian Holocaust: The Early Novel Psalm 44." AHEA: E-journal of the American Hungarian Educators Association, Volume 5 (2012): http://ahea.net/e-journal/volume-5-2012

inspector for the Yugoslav state railways. He apparently married Milica Dragićević in the first half of the 1930s and they had two children: first a daughter, Danica, and then Danilo.

As the war years ticked by, more and more discriminatory legislation against Jews was put in place in Hungary. Prime Minister Bárdossy's Third Jewish Law of August, 1941, for instance, forbade mixed marriages, defined as racially Jewish any person with at least two Jewish grandparents, ratcheted up the forced labor regime that affected at least 50,000 Jews, and allowed the SS to recruit among Germans living in Hungary. In addition, Jews and dissidents were sent to the Eastern Front in ill-equipped labor and penal battalions, along with a large number of regular Hungarian military units. Laws such as the numerus clausus for universities had been put in place as early as 1920, and discrimination in economic and political life was common. The socalled "First Anti-Jewish Law" was promulgated in 1938. In March 1942 Regent Horthy dismissed Prime Minister Bárdossy, probably because the Soviet victory at Stalingrad had convinced him that it was time somehow to reposition Hungary in the wartime constellation of powers; the new Prime Minister, Miklós Kállay, was more amenable to making overtures to the Western Allies. Various diplomatic openings were made to try to prepare for the inevitable (an Axis loss) and for the worst-case scenario (a vengeful Soviet occupation). But before any definitive links could be established with London or Washington, Hitler decided upon a drastic intervention in March 1944: the direct occupation of Hungary by German forces. In the spring and early summer of 1944, well over 400,000 Jews were rounded up and deported from Hungary in operations mobilized by Germans with Hungarian assistance (Lendvai 2003, 422). Most of the persons deported, members of the largest remaining Jewish population in the countries of Nazioccupied Europe, were killed in the death camps. Even after the deportations ceased, and Horthy attempted unsuccessfully to declare a cease-fire for all Hungarian military units, murderous attacks on the remaining Jewish population, especially in Budapest, were carried out by the followers of Szálasi, who had been handed control of the country in October, 1944 at Hitler's behest.

The Arrow Cross and its hangers-on had radical and muddled "Hungarist" and imperial ideas, but they had not always been lackeys of the Germans. Still, in the atmosphere of desperate ill-discipline and chaos, they were responsible for a great deal of continuing violence. They tried to control or redirect the expropriation of Jewish property for the government's benefit and tried to send only malnourished (or eventually no) forced laborers off to do service in the Third Reich; there were also new plans for a massive ghetto in Budapest and attempts to rename all topographic features in the capital reflecting Jewish heritage. This was the milieu in which the famous Swedish diplomat Raoul Wallenberg operated in 1944, but outside of the capital many of the ghettos had already been liquidated. Meanwhile, the Kiš family suffered greatly in the province. Kiš's father, Eduard, was first forced into labor brigades and into the Jewish ghetto at Zalaegerszeg. Then in 1944 he was caught up in the deportations and sent to Poland, where he disappeared at Auschwitz. Danilo Kiš himself had spent the first two years of his life in Szabadka, and the next five in Újvidék, where he was baptized for practical reasons into the Serbian Orthodox Church and attended first grade. To escape the increasingly strict and discriminatory legal atmosphere, the Kišes moved to Kerkabarabás in 1942. Kiš attended school there and in Zalabaksa through grade six. In 1947 the remaining Kišes returned to Cetinje, Montenegro (then part of Yugoslavia) to live with the Dragićević family.

The events in and around Novi Sad during the Hungarian occupation of the Vojvodina from 1941-1944 provide a useful case study for understanding the interplay of forces that produced discrete sets of atrocities amidst the general situation of war and officially mobilized 
Cox, John K. "Danilo Kiš and the Hungarian Holocaust: The Early Novel Psalm 44." AHEA: E-journal of the American Hungarian Educators Association, Volume 5 (2012): http://ahea.net/e-journal/volume-5-2012

and radicalized anti-Semitism in Hungary in general. In turn, Kiš 's novel treats these same events on the level of microhistory. The Novi Sad, or Újvidék, massacre of January 1942 is one of the three most salient episodes of anti-Jewish (and in this case, anti-Serbian) violence in wartime Hungary. The first was the massacre in recently occupied Subcarpathian Ruthenia, in the city of Kamenets-Podolsk in today's Ukraine, in August of 1941. Between 11,000 and 15,000 Jewish forced laborers were expelled from Hungary, in effect leaving them stranded in German hands. SS and Einsatzgruppen, assisted by Hungarian and Ukrainian forces and led by Lieutenant-General Franz Jäckeln, gunned them down between August 27 and 29. In 2011, the Hungarian government and the Holocaust Memorial Center in Budapest marked the seventieth anniverary of these killings; today a prominent plaque at the Center calls visitors' attention to this case of early and extreme violence and the role of the Hungarian forces to it. Scholars have also noted that---in a manner perhaps unexpected or even paradocixal, but fairly consistent---the conservative or right radical elites in Hungary, which were dominant throughout the war period, stopped these massacres, as they also did in the Novi Sad case described below. Some also maintain that these same conservative elites, said to have practiced "see-saw" politics vis-a-vis the Germans and Allies, also stopped the deportations at the conclusion of the German occupation in 1944 yet retained the entire extant raft of anti-Jewish legislation in a kind of domestic "see-saw" operation as well (Hanebrink 2006, 193-5). Other Axis allies in the region, such as Croatia, Romania, and Slovakia, mistrusted Hungary's relative "leniency in regard to the Jews" (Pók 1998, 50).

Although the Communist-led Partisans of Josip Broz Tito would eventually defeat the Germans and their collaborators in Yugoslavia, such as the Croatian fascists known as the Ustashe, most of the resistance was centered in the mountains of Bosnia-Hercegovina, Croatia, and Slovenia. The openness of much of Serbia's terrain made Partisan operations there difficult; another complicating factor for Tito and his maquis was the presence of what was initially a rival resistance group. This was the Chetniks, who were Serbian nationalist paramilitaries and former Yugoslav soldiers. Their leader was General Draža Mihailović, a Royalist, who later pursued his own anti-Communist agenda and engaged in some collaboration with the occupiers. Yet there were some sporadic outbreaks of guerrilla activity in Serbia, even in flat, open Vojvodina, now under Hungarian rule, and after one such outbreak in 1941, the Hungarian government ordered the Fifth Army Corps, based in Szeged, into action. Its commander, General Ferenc FeketehalmiCzeydner, was an extreme nationalist and resorted to, and condoned others' use of, extreme violence in counterinsurgency actions, including the execution of civilians. It has been suggested numerous times that Hungarian officers on this "southern front" were eager to see action there, even if in the framework of exaggerated threats, to forestall being transferred to the Eastern Front, where enormous peril and discomfort lay (Ungváry 2011, 78). Plans for regional expansion may have also played a role in the desire to keep Hungarian troops stationed locally: Budapest may have wanted both to prove to the Germans that they could handle the new territories they had been given and to be poised to take over southern Transylvania if a kind of "third Vienna award" should take shape (Tilkovszky 1990, 347-8).

At any rate, by early 1942 the government in Budapest saw no further need for drastic actions in the Vajdaság, but on January 23 the gendarmerie, army (Honvéd), and newly formed nemzetörségek (home guards, of both Hungarian and German ethnicity) ${ }^{3}$, making use of facilities provided by the Levente (an official nationalist Hungarian youth group) and led by local

\footnotetext{
${ }^{3}$ For more information, see the chapter entitled "The Délvidék Massacre" in Braham 1981, 207-215.
} 
Cox, John K. "Danilo Kiš and the Hungarian Holocaust: The Early Novel Psalm 44." AHEA: E-journal of the American Hungarian Educators Association, Volume 5 (2012): http://ahea.net/e-journal/volume-5-2012

commanding officer Colonel (or General) József Grassy (Ungváry 2011, 80) launched a carefully prepared massacre in Újvidék. Communications to the city were cut off, and a curfew imposed (Yahil 1990, 502-504); brutal interrogations and summary executions of purportedly subversive elements were carried out over a period of four days. At least two groups of people were mowed down in Miletić Street in the downtown area.The local prefect, Leó Deák, finally got a call out for help, and the central government in Budapest managed to halt the massacres. Several government officials and members of parliament in Budapest called for a halt to such abuses and for investigations; these elected officials included Endre Bajcsy-Zsilinszky as well as the lesserknown Milan Popovics. But the toll of the savage events was already great. Most notorious, and playing a salient role in the main character's flashbacks in Psalm 44, were the murders that took place, by a variety of means, on the banks of the Danube, in the very shadow of the enormous Petrovaradin fortress across the river. Today an imposing monument and memorial site mark the spot of the executions. The British historian Martin Gilbert, basing his numbers on the work of one of the pioneering scholars of Holocaust history, Raul Hilberg, sets the number of dead in those days in Novi Sad at 550 Jews and 292 Serbs (Gilbert 1986, 287). There were smaller massacres elsewhere in the region before the end of the month, notably in Titel, Szenttamás (Serb. Srbobran), Zsablya (Serb. Žabalj), Csurog (Serb. Čurug), and Óbecse (Serb. Stari Bečej).

It was after these "cold days" of January 1942 that the Kiš family returned to western Hungary, where Eduard had grown up. For the cities so important in Kiš's early life, however, Szabadka and Újvidék, the two and a half years following the massacres---that is, until the liberation and effective "repatriation" of the region by Tito's Partisans, with Szeged and points north being cleared of Axis forces by Soviet troops on their way northward to Budapest, which would not be liberated until well into January of 1945 ---was marked by three salient trends. First, the ghettoization of the Jewish population in urban centers around the country increased, and eventually these groups were deported. Second, after many months of investigation and hesitation by the Hungarian government, the " Újvidék" or "Bacska trials" of fifteen Hungarian military officers were held. Eventually the four main officers to be found guilty, including Feketehalmi-Czeydner, fled to Germany where they were given protection (!) as political refugees. Finally, a pattern of violence against both Jews and Serbs, as counterinsurgency, and against Jews, as institutionalized racism, continued in Hungary in various forms.

Different historians provide different measurements of the overall number of civilian casualties during the Hungarian occupation of the region. One measure is found in the accusations leveled against the officers in the Újvidék proceedings, who were charges with causing the deaths of 10,000 Serbs and Jews (Gilbert 1987, 287); the likely breakdown of those casualties is 6,000 Serbs and 4,000 Jews (Hilberg 1979, 521). Another is the total number of people killed in and around Újvidék during the whole period of occupation: 2,842 Serbs, 1,250 Jews, and small numbers of others (Yahil 1990, 502-504). A third is the total number of people killed just in Újvidék proper during the same period, or 2,300 Serbs and 1,000 Jews (Yahil 1990, 348-349).

Other wartime phenomena impinging upon life in the Vajdaság and on HungarianSerbian-Jewish relations include various resettlement plans, the Germans' use of Hungarian "Arbeitsjuden" (including the famous poet Miklós Radnóti) at mining and industrial sites in Serbia, and large-scale Serbian and Partisan deeds of revenge in the region at the end of the war. 
Cox, John K. "Danilo Kiš and the Hungarian Holocaust: The Early Novel Psalm 44." AHEA: E-journal of the American Hungarian Educators Association, Volume 5 (2012): http://ahea.net/e-journal/volume-5-2012

\section{Introduction to the novel Psalm 44 (1962)}

Since Psalm 44, now fifty years old, has been only infrequently translated, it makes sense here to give a recounting of it for those readers who do not know Serbian. The novel is set mostly in Auschwitz during World War II, with a brief epilogue also occurring there a few years later. The Hungarian material, which is plentiful, is introduced into the plot by a series of flashbacks. Psalm 44 is both a story about a young family in a death camp and a study of a woman's memories of growing anti-Semitism and persecution in and around Újvidék. The main characters, Marija and Jakob, a young doctor, are both Jewish and are both imprisoned at Auschwitz, or its associated camps. Most of Kiš's narrative about the death camp is devoted to a depiction of the miserable and brutal life in its women's section; the lovers have a baby in the camp, Jan, who survives the war, an extremely rare occurrence in the actual history of the camps but one which Kiš, as we know anecdotally, read about in a newspaper. Some of the chapters are presented as stream-of-consciousness narrative; others contain lengthy flashbacks; some passages combine the two techniques, often with abrupt returns to the central narrative set in the camp. The reader gets the strong impression that the characters, like the author, are trying to make sense of the unprecedented events (prejudice and discrimination and persecution in the eyes of a child in the Vojvodina at first, moving to the terror of the Final Solution) and to find a mode of expressing the experiences of the Shoah in words. Other flashbacks show how Marija and Jakob met and were able to be intimate in the camp. The book is also noteworthy for the detailed depictions of Marija's bodily condition, as well as that of her baby. These descriptions are sometimes graphic but not at all gratuitous, and they show considerable perspicacity on the author's part.

Besides the family of three, other important characters in the novel include an older and more savvy camp veteran, Žana; another woman prisoner, Polja, who dies in her bunk; and a friend of Jakob named Maks, who hold important jobs in camp and is able to help prisoners arrange meetings and deliver messages, and even help carry out escapes. The plot and chapter structure are relatively simple, even if the texture of the emotional and allusive prose is not. The characterizations are rather unique because of the unexpected and fitful ways the relationships and personalities are revealed to us. The characters fight, often in small but significant ways, to maintain a sense of human dignity. They also have more traditional "battles" such as their struggle against the sinister Dr. Nietzsche. This "renowned researcher" and "expert on racial issues" knows that the war is nearing its end and that he and the other Nazis will soon disappear. But he urges on Jakob a chilling, fanatical task: to ensure that the collection of Jewish medical specimens and skulls is not destroyed by the invading Soviet troops, because "this precious collection...could be all that remains of your extinct race" (Kiš 2012 Psalm, 50).

As Soviet forces are nearing the camp, Marija, Žana, and Jan escape. Amidst the ravages of mass death, hunger, illness, cold, and deportations, Jakob also survives, but the lovers are separated. Marija works for a German woman who runs a tavern, while Jakob is moved through a series of hospitals or displaced-person camps before preparing to emigrate to North America. Marija and Jakob eventually find each other and start a new life together in Warsaw. In the final chapter, or epilogue, they visit Auschwitz with their son, whom they consider old enough to begin to share this historical burden with them. In a final dramatic flourish, they find out at the camp that Maks, their deus ex machina, works there as a docent, and Marija and Jan meet him for the first time.

The Hungarian content in Psalm 44 breaks down into several discrete categories. In the camp itself, for instance, there is only one other Hungarian mentioned, a woman to whom Kiš 
Cox, John K. "Danilo Kiš and the Hungarian Holocaust: The Early Novel Psalm 44." AHEA: E-journal of the American Hungarian Educators Association, Volume 5 (2012): http://ahea.net/e-journal/volume-5-2012

refers by the Serbian variant of her name, Eržika Kon. She is mentioned several times as part of work and barrack life; Kon is shot to death along the barbed wire of the camp fence in an escape attempt. The rest of the information on Hungary and Hungarians is transmitted through the flashbacks. At one chronological remove backwards are Marija's recollections of the night she and Jakob first had sex in Jakob's room in the men's barracks, followed and preceded by other flashbacks delineating the difficulties of communicating with him about her pregnancy and escape plans. Roughly in the middle of the backwards-looking chronology of the story are the numerous brief references to the anti-Semitic and anti-Serbian atrocities carried out by Hungarian forces during "Cold Days" of 1942 in Novi Sad. Going further back in time, presumably to the late 1930s or early 1940s, we encounter Edi, who is Marija's father, as well as her mother, whose name we do not learn; there are also relatives and family friends such as Aunt Lela, Mr. Rozenberg, and the carpenter, Čika Martin and his daughter Anijela. The marginally most distant memories are those from Marija's summer experiences in a village or camp in Vojvodina, where she meets Catholic priests with a film projector and suffers abuse at the hands of another vacationing girl from her hometown, Ilonka Kutaj. One of the flashbacks is so extensive that it goes back three levels in time: to the night in Jakob's room, and while Marija is hiding in the closet during the unexpected visit of Nietzsche, to the visit in her hometown to the carpenter's workshop where Anijela was also hiding, and from there in her thoughts to what she had heard about an old man in their town who was arrested for his prophecies about war just after the Sarajevo assassination back in 1914.

\section{Salient Points and Passages of the Book}

Although the Shoah pervades, and indeed forms the foundation of, much of Kiš's oeuvre, there he took certain risks in this early novel that resulted in unique passages of text. These passages include the great violence of the scenes of the "Cold Days" and the interior monologues by Marija that form the narrative structure of much of the book. In addition, there are many intricate and poignant scenes in the book that show enormous expressive power and include penetrating, if understated, historical knowledge. One of the unique features of this novel is the considerable degree to which the story line is rooted in urban and village life in the largely Hungarianpopulated territories of what became northern Serbia (de jure Kingdom of Serbs, Croats, and Slovenes and then by the time of Kiš's birth Yugoslavia) after the Great War. Many of the most unforgettable scenes occur in flashbacks, as when Marija thinks back to her encounter, in the presence of her Aunt Lela in Újvidék (Novi Sad), with the carpenter's family in their workshop for coffins:

and she thought back to the heavy aromatic smell of chestnut blossoms and to that cul-de-sac pulling off of Grobljanska Street and then going left. Now she could remember also the ice-flowers on the window between which appeared the head of the gray-haired old man like the head of some faun amongst the ferns, and she recalled his mouth of crooked and missing teeth below his big mustache when their round faces filled the opaque flowers of the window while he exhaled on it to melt the ice. Then, under his reeking breath, the fern withered, and Aunt Lela pulled the scarf away from her face so that he would recognize 
Cox, John K. "Danilo Kiš and the Hungarian Holocaust: The Early Novel Psalm 44." AHEA: E-journal of the American Hungarian Educators Association, Volume 5 (2012): http://ahea.net/e-journal/volume-5-2012

her: "It's us, Čika Martin", ; then a flickering yellow light came on in the window and after that one could hear the key turning in the lock and she saw the faun's dishevelled head and mustache and immediately she regretted coming, even before the man said: "This one's not coming to me for a place to stay, is she?" But Aunt Lela said:

"No. She's not. She just came by to see Anijela. How is Anijela?"

They stood in the corner of his darkened workshop and warmed up by the low fire smoldering in a round sawdust-fed stove. Two or three times the man lifted the lid and peered in at the embers, each time spitting into the fire and then sticking his pipe back in his mouth. But she had still not seen Anijela. They were waiting until they had warmed up a bit, but she had already firmly decided that she would not be staying, whatever happened. It wasn't precisely on account of the old man but much more because of the low ceiling, smoky and peeling, and due to the sensation of death abiding in everything; she almost couldn't look at that black gilt-edged coffin lid standing upright by the door.

"She sleeps all the time," the old man said. He took the pipe out of his mouth. Then with his middle finger he tamped down the fire in his pipe and she saw that the stunted index finger on his right hand was fastened to his index finger like some sort of parasite. "I tell her it would be better for her to get some exercise," he said. "It's impossible for anybody to come in here without my hearing them first. But she does not want to get up until it passes, as she says. All this must pass"...

Then the man repeated:

"You see? I told you. She's sleeping again," and he raised the lid from one of the caskets in the corner of the room. "All she does is sleep. In the evenings she comes out, only to go to one place. Then she goes right back." Then he told her: "She has feathers in there. And the chimney runs along beside her there. She's not cold, she says."

Just then she caught sight of Anijela: who slowly raised her eyelids, and then only the whites of her eyes showed, and these words came dragging out of her mouth:

\footnotetext{
${ }^{4}$ Čika Martin: the Serbian equivalent of "Martin bácsi"---"Mr. Martin" or "Uncle Martin" in English would indicate a similar sense of adult male family friend.
} 
Cox, John K. "Danilo Kiš and the Hungarian Holocaust: The Early Novel Psalm 44." AHEA: E-journal of the American Hungarian Educators Association, Volume 5 (2012): http://ahea.net/e-journal/volume-5-2012

I'm always sleepy," Anijela said. "As soon as I let the lid down, I

fall asleep." Her eyes were twitching as if the meager illumination of the candle were blinding her" (Kiš 2012 Psalm, 27-9).

In Psalm 44 children, as in the case here of Anijela and even more obviously, in the case of Marija's son Jan, who is born in the death camp, are constantly exposed to direct experience of war and the Holocaust. In other works, Kiš typically stressed the indirect contact with the Holocaust, as in the narrator's memories of his schoolboy days in Night and Fog and in all three works, in both the short story and the novel genre, of the illustrious "family circus" series. Another flashback to life in the Vajdaság extends even further into the narrator's past. Once in the death camp she catches site of her lover, Jakob, engaged in manual labor, and it reminds her of the first motion picture she had ever seen in a remote village once over summer vacation. Yet the idyllic memories and modern sensibilities are incomprehensibly laced with antiSemitic venom even back then:

and Ilonka Kutaj said to her back then, coming home from school: "Your father crucified Christ": and then she added, so that people could see what she meant when she said "Your father crucified Christ": -- "Or he at least gave them the nails," and then she continued: "And you gave them nails, too," and Ilonka's mother told her: "Stop talking that way, sweetheart, as if Marija were guilty. She wasn't even born yet, and neither was her father," but then Ilonka jeered: "Neither was her great-great-grandfather," and then: "You told me yourself that all the Jews are responsible for the death of the Son of God; --so you said -- they contributed nails at least; and didn't I hear you say that at least five hundred and fifty million times, a billion times, a trillion?" (Kiš 2012 Psalm, 72-73)

The local anti-Semitism inherent from the narrator's youth explodes into beastly violence in the "cold days" of 1942, when hundreds of Jews and Serbs were executed by Hungarian forces on the banks of the Danube at Újvidék. This notorious massacre, which Kiš often discussed in his interviews and which his father only barely survived, is also the subject of the 1964 novel Cold Days by Tibor Cseres and is discussed in Aleksandar Tišma's better-known novel, The Book of Blam. Although Kiš's other writings are capable of generating a frightening and oppressive atmosphere of doom and also occasionally evince flashes of beastliness, the author grew more and more to embrace a kind of ironic distance to both his family history and to politics and violence in general. His interviews demonstrate that he had not yet adopted this narrative technique at the time of the writing of Psalm 44. Thus, the violence of the "cold days" is more diabolical and more explicit in the following passage than elsewhere in his works. Here, the narrator, Marija, is recalling what she and a neighbor, Mr. Rozenberg, had seen a few hours earlier at the assembly point by the Danube: 
thus she was able to see all of the things that the younger Mr.

Rozenberg had seen, after he had already gotten beyond the green peeling fence and she could now imagine almost as well as he could that face with the bristly beard as Kenjeri pressed a woman's neck into the snow with his heavy boot (and she thought that it was the very same woman who had gotten undressed after the old man) and she could see, on the spot where there had once been a face (which she could no longer remember), a monstrous stain of concentrated terror, there where before there had been eyes and the lines of a face petrified by cold like when bronze gives off a green patina through its wrinkles; and she could remember everything as if she experienced it herself: how the boy (judging by his wolfish jaws, the son of that swindler) held the nearly dead woman by the legs and the way the woman writhed like a slaughtered hen when the teeth of the saw tore into the flesh on her side and the way the man then uttered "prrrr" and him snapping at his son "Steady, you moron!" And the way the son clenched his teeth and tightened his grip on the woman's legs and then the man pulling the saw back a bit and pushing it forward and then drawing the serrated tool back forcefully towards himself when the steel found its way down between two vertebrae in her backbone and how, with streams of blood gushing and flooding out into the snow on both sides, the saw began to squish and slip on intestines and flesh. Then, the man snapping at the youth once more, "Forget the bitch. I guess her legs won't be running off without her head," and the younger Kenjeri, still squeezing the woman's legs and his body twitching and shaking and the man staring at him in amazement, showing his dirty horse-like teeth afresh and in protest: "What's wrong with you, you idiot? Is it that you aren't used to blood, or do you feel sorry for that whore?" And how he pushed the boy with the handle of the saw and how the boy abruptly dropped the woman's legs and tumbled over into the snow and rolled over onto his belly and submerged his big curly head in the white-and-bloody snowy mush; then the man talking while the boy shook with sobs: "Let's get these here ready and then we'll talk," then to placate, to instruct, "it's easier to saw than to bust up ice," then the youth slowly, indifferently, getting to his feet without raising his head (just excremental snow in his dark hair), then him wiping his nose with the back of his hand and picking up the legs of the new victim, gnashing his teeth with the strain, while the man took hold once more of his tool after having taken the preliminary step of pressing the sundered body through the hole, and under the ice; she even heard that melody that the wind brought from the left bank of the Danube and she felt each revolution of the gramophone disk 
leaving behind on her bloody bites from the steel needle: the Blue Danube Waltz was still fashionable at that time; and then all of a sudden Aunt Lela was standing in front of Mr. Rozenberg and making him snap out of it by exclaiming to his face:

"Enough, Solomon, I beg you," and then, as he stared into space; "Stop, Solomon. Don't go any further with this," and then she spoke and was amazed at hearing her own voice in this way:

"I saw it all, too..." (Kiš 2012 Psalm, 103-6)

Even before undergoing this repulsive initiation by violence (and there is more of it in the text than is reproduced here) and before reaching her emotional nadir in the camp, Marija has a transformative discussion with her father. It occurs in their home in Újvidék upon her return from the village mentioned in the second example above. Her mother is attempting to dissuade Marija from mentioning the hateful taunts of the village children when, on the way home from the train station, they realize that there are now signs forbidding Jews to ride the streetcars:

and then she heard her mother' voice, like a rebuke:

"My God, you aren't a child any more! Don't you see anything around you that might tell you something?" and then, as if she were pointing out in a primer to someone who did not yet know all the letters or who was pretending not to know them or not to see them: "Read that. There, you see, the white letters. By the door...Do you understand? You speak good German...Yes, that placard on the streetcar. Next to the door. FÜR JUDEN VERBOTEN. Do you understand: für Juden verboten?. Do you understand now?" -- and she grasped it all immediately, at least as far as the translation from German went, of all things her mother had not needed to translate that, but she understood something else in the murky fabric of events, but still there was not sufficient reason to alter the expression on her face or to stop pursing her lips like that, like a cantankerous little witch, and then she resolved firmly and just for the sake of spite to tell her father everything, in order to find out the remainder, of what she did not know, but that remainder of the truth that was hiding from her but that she must ultimately find out, lest she remain or become a genuinely cantankerous witch and go on pursing her lips, until she finally came to know what it meant that people all of a sudden, while she was in the village, had written FÜR JUDEN VERBOTEN on the streetcars, that is to say why this was so, so that she was no longer allowed to ride on the streetcar, 
Then with the yellow one, Mama

Not with the yellow one either

Child, you aren't allowed on any streetcar

Understand: not on any

But can Ilonka Kutaj ride then?

the way Ilonka Kutaj can, for instance, this chatterbox stupid louse-ridden ignoramus urchin a D-student at the bottom of the class on whose account she had to flee the village and get into an argument with her mother and now she'll have to have one, too, with her father and she'll quarrel with the entire world, too, if necessary, or she'll put on a pouty face even if it makes her uglier than the ugliest toothless crone, she had made her that mad; and still she heard the voice of her father (he had started speaking suddenly after everything she had dumped on him so she knew she had done the right thing in telling him everything even if she had no real reason too, because her father had not been irritated when her mother said that they had returned because they weren't enjoying the village and because she had gotten diarrhea and the measles because she was allergic to the village diet, he only said "It would have been better if you had stayed there and stuck it out, until things here calm down") and she knew that she had done the smart thing in telling her father everything regardless...(Kiš 2012 Psalm, 79-80).

\section{Conclusion}

In this fine novel, then, we see early examples of two thematic concerns that fueled Kiš's writing for his whole life. He makes a careful study of persecution; in this case the imperilled "other" is a Jewish woman, but elsewhere Kiš would study the effects of marginalization, intolerance, and violence on many diverse characters, as mentioned in the introduction to this essay. We also witness here Kiš's preoccupation with the disappearing human and material past of "Pannonia," as Kiš called his enormous home geo-cultural region; the detail in his flashbacks in this novel is the first sign of his recognition that Pannonia must be preserved in part by literary means (eventually involving the postmodern technique of "listing" or enumeration).

As the Austrian critic Karl-Markus Gauss put it, Kiš retrieved things

from memory with gentle urgency, because what has been lost, what has vanished, must be named and saved. The loss is not so much from slipping into the nameless abyss of the years but from the fact that the old world itself no longer exists: in Kiš's case this was Pannonia, where many different peoples left their tracks (Gauss 1992, 149).

The writing in this particular book is anything but gentle. Direct treatment of medievalstyle executions precludes that kind of tone, and Kiš was still in the process of forumulating an artistic mission that would view enumeration and, especially, the graceful and elegiac description of familiar objects, as indispensable tools of style. But in Psalm 44 we do have a worthy 
supplement to the three books of the "family circus." at the same time, this is Kiš's only major piece of "camp literature" relating to World War II; the stories of A Tomb for Boris Davidovich provide, in a much different way, a kind of parallel for the Gulag, a creative "bookend" at the other end of the political spectrum. Psalm 44 is also significant because it calls our attention to the role of non-German collaborators and to an instance of one of the extra-camp masacres, like Kamenets-Podolsk or Babi Yar, that occurred in the early evolution of the Nazi-led Holocaust.

In this early novel, memories broached by the characters are not elusive or misleading as in later works; whereas the young narrator in Garden, Ashes and Hourglass often chafes at the contradictions and gaps in the memories available to him, the memories in Psalm 44 are more directly historical, sediment-like, backfilling the story in a way that is both clear and supportive of the development of plot and characters in the "present tense" of life in the death camp. What is problematic in Psalm 44 is not Marija's ability to remember but her capacity to grasp what is happening around her; the Holocaust is too ghastly and enervating to be readily understood or negotiated, mirroring the efforts of Kiš as a young writer, in both this novel and its contemporary, The Attic, to forge an idiom capable of delivering his thoughts and historical sensibility.

\section{Works Cited}

Bauer, Yehuda. 2001. A History of the Holocaust. New York: Franklin Watts.

Braham, Randolph. 1981. The Politics of Genocide: The Holocaust in Hungary. Volume I. New York: Columbia University Press.

Braham, Randolph L. 1993. "The Kamenets-Podolsk and Délvidék Massacres:

Prelude to the Holocaust in Hungary." Yad Vashem Studies 9: 133-156.

Braham, Randolph L. and Scott Miller, eds. 1998. The Nazis' Last Victims: The Holocaust in Hungary. Detroit: Wayne State University Press in association with the United States Holocaust Memorial Museum.

Braham, Randolph L. and Bela Vago, eds. 1985. The Holocaust in Hungary: Forty Years Later. New York: Social Science Monographs, the Institute for Holocaust Studies of the City University of New York, and Institute for Holocaust Studies of the University of Haifa.

Cseres, Tibor. 2003 (1964). Cold Days. Translated by Bernard Adams. Budapest: Corvina.

Gauss, Karl-Markus, ed. 1992. Das Buch der Ränder. Klagenfurt: Wieser.

Gilbert, Martin. 1986. The Holocaust: A History of the Jews of Europe during the Second World War. New York: Holt, Rinehart, and Winston.

Hanebrink, Paul A. 2006. In Defense of Christian Hungary: Religion, Nationalism, and Anti-Semitism, 1890-1944. Ithaca: Cornell University Press.

Hilberg, Raul. 1979. The Destruction of the European Jews. New York: Harper and Row.

Kiš, Danilo. 1994. Garden, Ashes. Translated by William J. Hannaher. New York: Harcourt Brace.

Kiš, Danilo. 2009. Night and Fog. Translated by John K. Cox, in Absinthe: New European Writing. 12: 99-133.

Kiš, Danilo. 2012. The Lute and the Scars. Translated by John K. Cox. Champaign, IL: Dalkey Archive Press.

Kiš, Danilo. 2012. Psalm 44. Translated by John K. Cox. Champaign, IL: Dalkey Archive Press. Kontler, László. 2002.A History of Hungary. New York: Palgrave Macmillan. 
Lendvai, Paul. 2003. The Hungarians: A Thousand Years of Victory in Defeat. Princeton: Princeton University Press.

Molnár, Miklós. 2001. A Concise History of Hungary. New York: Cambridge University Press.

Pók, Attila. 1998. "Germans, Hungarians, and the Destruction of Hungarian Jewry" in Randolph L. Braham and Scott Miller, eds., The Nazis' Last Victims: The Holocaust in Hungary. Detroit: Wayne State University Press in association with the United States Holocaust Memorial Museum, 1998.

Radič, Viktorija. 2005. Danilo Kiš:Život, delo i brevijar. Translated from the Hungarian by Marko Čudić. Beograd: LIR BG.

Ramet, Sabrina P. and Ola Listhaug, eds. 2011. Serbia and the Serbs in World War II. New York: Palgrave Macmillan.

Sugar, Peter, and Péter Hanak and Tibor Fránk, eds. 1990. A History of Hungary. Bloomington: Indiana University Press.

Tilkovszky, Loránd . 1990. "The Late Interwar Years and World War II," in Peter Sugar, et al., eds. A History of Hungary. Bloomington: Indiana University Press.

Tišma, Aleksandar. 1998. The Book of Blam. Translated by Michael Henry Heim. New York: Harcourt Brace.

Ungváry, Krisztián. 2011. "Vojvodina under Hungarian Rule," in Sabrina P. Ramet and Ola Listhaug, eds. Serbia and the Serbs in World War II. New York: Palgrave Macmillan.

Yahil, Leni. 1990. The Holocaust: The Fate of European Jewry, 1932-1945. Translated by Ina Friedman and Haya Galai. New York: Oxford University Press. 